\title{
Sindrom Wiskott Aldrich: Laporan Kasus
}

\author{
Nita Ratna Dewanti, Zakiudin Munasir
}

Sindrom Wiskott Aldrich (SWA) merupakan kelainan genetik imunodefisiensi yang diturunkan secara $X$-linked recessive, termasuk dalam sindrom hiper IgE. Kasus ini sangat jarang, insidens di Amerika Serikat 4:1000000 kelahiran bayi hidup laki-laki. Manifestasi klinis SWA berupa eksima, trombositopenia, dan infeksi berulang. Biasanya meninggal usia dini. Dilaporkan kasus pertama di RS Cipto Mangunkusumo, Jakarta yaitu bayi laki-laki, 4 bulan, BB 3,8 kg ( $\left.<\mathrm{P}_{5} \mathrm{NCHS}\right), \mathrm{PB} 55 \mathrm{~cm}\left(<\mathrm{P}_{5} \mathrm{NCHS}\right)$ dengan riwayat buang air besar berdarah, purpura dan petekie, demam berkepanjangan, eksim, trombositopenia dan infeksi berulang berupa sepsis, pneumonia, dan bula di paru kanan. Pada pemeriksaan fisis didapatkan anak sadar, aktif, suhu $38^{\circ} \mathrm{C}$, konjungtiva pucat, pada telinga terlihat vesikel, eritem, dan keropeng. Didapatkan mengi pada pemeriksaan paru dan hepatosplenomegali. Pemeriksaan penunjang didapatkan anemia, leukositosis, dan trombositopenia, tidak ditemukan sel blast pada gambaran darah tepi dengan ukuran trombosit kecil. LED meningkat. Analisis tinja didapatkan malabsorbsi lemak. BMP menunjukkan hipoplasia eritropoesis dan trombopoesis. Pemeriksaan radiologis toraks ditemukan bula paru kanan. Kadar IgA 43 mg/dl, IgG 1428 mg/dl, IgM 102 mg/dl, C3 dan C4 normal, IgE total $5350 \mathrm{mg} / \mathrm{dl}$. Uji Coombs direk positif, indirek negatif, isohemagglutinin tidak dapat diperiksa. Pasien didiagnosis sebagai Sindrom Wiskott Aldrich, bula paru kanan, gagal tumbuh dan diare kronik. Pasien diberi transfusi packed red cell (PRC) dan suspensi trombosit, antibiotik, diet elemental dan methisoprinol. Pasien meninggal pada usia 5 bulan karena gagal nafas akibat infeksi paru yang berat.

Kata kunci: $x$-linked recessive, eksima, trombositopenia, infeksi berulang.

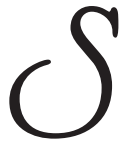

indrom Wiskott Aldrich disebut juga sebagai sindrom eksim-trombositopenia imunodefisiensi merupakan kelainan genetik yang diturunkan secara $x$-linked recessive, termasuk kelompok sindrom hiper IgE. Kasus SWA sangat jarang ditemui sehingga sering luput dari diagnosis karena kesulitan mengenalnya. Gejala trombositopenia sering didiagnosis sebagai ITP, sedangkan gejala eksim sering

Subbagian Alergi Imunologi. Bagian Ilmu Kesehatan Anak FKUI-RSCM. Jakarta (Dr. Zakiudin Munasir, Sp.A(K). PPDS Bagian Ilmu Kesehatan Anak FKUI-RSCM, Jakarta (Dr. Nita Ratna Dewanti).

Alamat korespondensi:

Dr. Nita Ratna Dewanti.

PPDS Bagian Ilmu Kesehatan Anak FKUI-RSCM. Jl. Salemba No. 6, Jakarta 10430.

Telepon: 021-3148610. Fax. 3913982. diduga sebagai dermatitis atopi pada pasien alergi. Komplikasi tersering adalah infeksi dan perdarahan yang merupakan penyebab tersering kematian. ${ }^{1-3}$

Laporan ini merupakan kasus demontrasi, sehingga diharapkan di kemudian hari tidak luput dari diagnosis. Perlu diingatkan bahwa pasien dengan infeksi berulang oleh karena daya tahan tubuh lemah perlu dipikirkan adanya imunodefisiensi.

\section{Kasus}

Seorang bayi laki-laki berusia 4 bulan saat pertama kali berobat ke Subbagian Alergi-Imunologi Bagian Ilmu Kesehatan Anak FKUI-RSCM pada tanggal 5 Februari 2001 dengan keterangan demam berkepanjangan, hematokezia berulang, purpura trombositopenia 
idiopatik dan diduga suatu kelainan imunodefisiensi. Dari riwayat penyakit dahulu didapatkan sejak anak berusia 2 hari buang air besar mencret dan selalu bercampur darah segar, pada kulit terdapat bercak kebiruan dan bintik-bintik merah. Pasien juga menderita demam yang hilang timbul sejak lahir. Suhu pasien tidak pernah normal selalu berkisar antara $38-39,5^{\circ} \mathrm{C}$. Pasien dirawat beberapa kali di rumah sakit dengan diagnosis sepsis dan mendapat antibiotik namun tidak ada perubahan, buang air besar tetap bercampur darah dan selama perawatan jumlah trombosit pasien tidak pernah lebih dari 57.000/ul. Pasien kemudian dirujuk ke RSCM ke Subbagian Hematologi dengan keterangan hematokezia berulang dan ITP kongenital. Berdasarkan hasil aspirasi sumsum tulang, ditegakkan diagnosis anemia hipoplastik dan diobati metil-prenisolon $2 \times 3 \mathrm{mg}$, orgabolin $1 \times 3 \mathrm{mg}$. Pasien pernah dirawat di RSCM dengan pneumonia bakteri kokus dengan bula paru kanan, pasien mendapat terapi linkomisin. Pasien berobat jalan dengan terapi salbutamol dan azitromisin. Pasien adalah anak tunggal, lahir dengan seksio sesaria atas indikasi letak lintang, lahir prematur ( 8 bulan kehamilan), selama hamil ibu tidak menderita suatu penyakit. Berat lahir 2.400 gram, panjang lahir $45 \mathrm{~cm}$, dan anak langsung menangis. Saat ini anak sudah dapat tengkurap. Anak mendapat pengganti ASI dan telah mendapat imunisasi BCG.

Ayah berusia 33 tahun, suku Jawa, pendidikan sarjana, bekerja sebagai karyawan swasta. Ibu berusia 27 tahun, suku Jawa, pendidikan Diploma III, ibu rumah tangga. Pemeriksaan fisis tanggal 5 Februari 2001, didapatkan seorang bayi laki-laki tampak sakit sedang dengan berat badan 3.800 gram ( $<$ P5 NCHS), panjang badan $55 \mathrm{~cm}$ (<P5 CNHS). Kesadaran kompos mentis, tidak sesak maupun sianosis. Laju nadi=laju jantung 104 $\mathrm{x} / \mathrm{m}$, laju pernafasan $32 \mathrm{x} /$ menit, suhu $38^{\circ} \mathrm{C}$. Kulit terdapat petekie dan eksim pada pipi. Pada wajah tidak terdapat deformitas. Konjungtiva pucat, sklera tidak ikterik. Pada telinga terdapat bercak eritem, keropeng dan vesikel, hidung dan tenggorok normal, pada leher tidak teraba pembesaran kelenjar getah bening. Dada simetris, auskultasi paru terdengar vesikuler, tidak ada ronki dan lendir, terdapat mengi. Bunyi jantung I dan II normal, tidak terdengar bising dan irama derap. Perut lemas, turgor cukup, hati teraba _ - _ kenyal rata, tepi tajam, limpa SII, bising usus (+) normal. Alat gerak akral hangat tidak terdapat parut BCG. Pemeriksaan darah tepi didapatkan kadar hemoglobin $8,9 \mathrm{~g} / \mathrm{dl}$, hematokrit 28,5 vol\%, eritrosit 3,53 juta $/ \mathrm{ml}$, leukosit $13.400 / \mathrm{ml}$, trombosit $43.000 / \mathrm{ml}$. Hitung jenis (\%), eosinofil 1, basofil 1, batang 5, segmen 68, limfosit 20, monosit 5 . Pada gambaran darah tepi tidak terdapat sel blast dan bentuk trombosit kecil. PT 12 menit, APTT 35 menit. Laju endap darah $70 \mathrm{~mm} / \mathrm{jam}$. Pada pemeriksaan feses didapatkan eritrosit penuh, leukosit 20-25/LPB, lendir $(+)$, lemak (-), sisa makanan (+), telur cacing (-), amuba (-). Analisis tinja didapatkan malabsorbsi lemak dianjurkan penambahan susu formula yang mengandung asam lemak tidak jenuh. Aspirasi sumsum tulang didapatkan kesan hipoplasi eritropoesis, trombopoesis dengan ukuran trombosit kecil. Hasil biakan darah dan tinja negatif. Pemeriksaan TORCH didapatkan anti toksoplasmosis IgM negatif, IgG positif $12 \mathrm{IU} / \mathrm{ml}$, anti rubella IgM negatif, IgG positif $422,1 \mathrm{IU} / \mathrm{ml}$, anti CMV IgM negatif, IgG positif $37 \mathrm{AU} / \mathrm{ml}$, anti virus Herpes simpleks-1 IgM negatif, IgG positif rasio 2,44 anti virus Herpes simpleks-2 IgM dan IgG negatif. Gambaran radiologi toraks didapatkan adanya bula paru kanan. Subbagian Alergi-Imunologi menganjurkan pemeriksaan kadar imunoglobulin dengan hasil sebagai berikut: kadar IgA 43/dl (N: 10-131 mg/dl), IgG 1428 mg/dl $(\mathrm{N}: 190-860 \mathrm{mg} / \mathrm{dl}), \mathrm{IgM} 102 \mathrm{mg} / \mathrm{dl}(\mathrm{N}: 25-120 \mathrm{mg} /$ dl), komplemen C3 $119 \mathrm{mg} / \mathrm{dl}(\mathrm{N}: 55-120 \mathrm{mg} / \mathrm{dl})$, komplemen C4 $24 \mathrm{mg} / \mathrm{dl}$ (N: 10-40 mg/dl), IgE total $5350 \mathrm{IU} / \mathrm{ml}$ (N: 0-6, $62 \mathrm{U} / \mathrm{ml})$. Hasil uji Coombs direk didapatkan hasil positif dan indirek negatif. Direncanakan pemeriksaan isohemaglutinin untuk menilai fungsi imunoglobin namun tidak dapat dikerjakan karena tidak tersedia reagen. Pada akhirnya ditegakkan diagnosis sindrom Wiskot Aldrich, bula paru kanan, gagal tumbuh dan diare kronis.

Pasien diobati secara simtomatis dengan pemberian packed red cell $60 \mathrm{ml}$ dan suspensi trombosit serial 1 kantong, metil prednison dan orgabolin dihentikan sedangkan linkomisin dan salbutamol diteruskan. Pasien juga diberi methisoprinol dosis $50 \mathrm{mg} / \mathrm{kgBB}$ dibagi 3 dosis diberikan setiap 3 hari dalam seminggu, selama 12 minggu. Untuk pengobatan eksim diberikan mometason topikal (krem).

Pada tanggal 7 Maret 2001 pasien kembali dirawat di RSCM untuk keluhan sesak nafas dan buang air besar berdarah. Pada pemeriksaan fisis juga didapatkan gejala dermatitis yang semakin jelas. Pemeriksaan darah tepi saat itu Hb 7,4 g/dl, Ht 20 vol\%, leukosit 21.400/ $\mathrm{ul}$, trombosit 14.000/ul. Analisis gas darah $\mathrm{pH} 7,379$, $\mathrm{pO}_{2}$ 164,8 $\mathrm{mmHg}$ (dengan oksigen 2 liter/menit), $\mathrm{PCO}_{2} 19 \mathrm{mmHg}, \mathrm{HCO}_{3} 11,3 \mathrm{mEq} / \mathrm{l}$, base ekses 14,1 $\mathrm{mEq} / \mathrm{l}$. Pada pemeriksaan foto toraks ditemukan giant 
bulae. Pasien mendapat antibiotik intravena serta transfusi PRC dan trombosit. Atas permintaan orang tua pasien pulang pada hari ke-4 perawatan, tampak perbaikan. Pada tanggal 13 Maret 2001 pasien kembali sesak nafas hebat dan sianosis, dirawat di ICU Anak dengan ventilator dan antibiotik. Pasien meninggal pada tanggal 14 Maret 2001 dengan gagal napas.

\section{Diskusi}

Apabila dijumpai pasien dengan gejala trombositopenia kongenital dan hiper IgE, perlu dipikirkan sindrom Wiskott Aldrich. Sindrom Wiskott Aldrich merupakan kelainan genetik yang diturunkan secara $x$-linked recessive dengan gambaran klinis berupa eksim, trombositopenia dengan bentuk trombosit yang kecil, serta menderita penyakit infeksi berulang. Sel limfosit B dan $\mathrm{T}$ gagal membentuk antibodi terhadap antigen polisakarida. Sindrom ini dapat menyebabkan kematian di usia dini. Tidak semua individu yang menderita sindrom ini memiliki gambaran klinis lengkap. Sindrom ini pertama kali dikemukakan oleh Wiskott di tahun 1937. Baru kemudian di tahun 1954 Aldrich dan kawan-kawan menganalisis adanya hubungan genetik secara $x$-linked pada sindrom ini. ${ }^{1-3}$

Angka kejadian SWA di Amerika Serikat sangat jarang, berkisar antara 4:1000000 kelahiran hidup bayi laki-laki. ${ }^{5}$ Di RSCM baru kali ini ditemukan kasus SWA. ${ }^{1,5}$ Kasus perempuan sebagai karier pernah dilaporkan mempunyai manifestasi klinis SWA yang nyata sebagaimana yang dilaporkan Parolini $\mathrm{dkk} .^{6}$

Secara genetik kelainan SWA terletak pada lokasi gen di lengan pendek Xp $11.22-11.23$. Riwayat keluarga biasanya didapatkan pada $50 \%$ individu. ${ }^{4}$ Dari kepustakaan didapatkan bahwa kelainan gen yang diturunkan pada SWA berpengaruh pada satu atau lebih sel hematopoitik (selain sel darah merah), ekspresi dari permukaan sel protein CD43 tidak aktif, abnormalitas dari glycosyl transferase, mikrovili permukaan sel $\mathrm{T}$ sedikit, kelainan pada tempat penyimpanan trombosit, aktivasi/ekspresi dari fungsi sel limfosit B, produksi IgA lebih dari 9x normal, SWA menyebabkan gangguan sitoskleton pada sel yang terkait. $^{1,7-9}$

Faktor risiko pada SWA adalah adanya riwayat keluarga dengan kelainan kongenital..$^{3-4}$ Pada pasien ini tidak terdapat kelainan bawaan dalam keluarga. Pemeriksaan ke arah infeksi kongenital seperti
TORCH, kesan normal.

Masa awitan SWA adalah masa neonatus/bayi lakilaki. Biasanya pada usia satu tahun pertama akan menderita infeksi yang disebabkan oleh pneumokokus dan bakteri lainnya, seperti otitis media, pneumonia, meningitis, atau sepsis. Infeksi lain yang dapat terjadi adalah infeksi oleh P.carinii atau herpes. Jarang ditemukan pada usia lanjut karena jarang pasien SWA yang selamat sejauh ini. ${ }^{1,2,8}$ Pada pasien ini telah mengalami infeksi berulang berupa pneumonia. ${ }^{1,3}$ Sayangnya etiologi pneumonia tidak ditemukan, namun melihat gambaran rontgen paru kemungkinan infeksi oleh stafilokokus atau pneumokokus.

Tanda dan gejala SWA pada masa neonatal berupa buang air besar berdarah, petekie dan purpura. Pada masa anak-anak berupa eksim (dalam 1 tahun pertama), infeksi kulit, pneumonia, otitis media, infeksi herpes (pada kulit dan mata), hepatosplenomegali, sehingga sindrom ini disebut pula sebagai sindrom eksimtrombosipenia imunodefisiensi. Pada pasien ini juga didapatkan adanya buang air besar berdarah sejak usia 2 hari, dan terdapat bercak kebiruan serta bintikbintik merah ke kulit. Pada telinga terdapat eksim, riwayat menderita pneumonia dan terdapat hepatoslenomegali.

Pada pemeriksaan darah tepi, didapatkan kadar trombosit kurang dari 30.000/ul dengan bentuk yang kecil MPV 2/3 normal, (trombositopenia dan trombosit yang kecil) pada saat lahir. Kadar IgM dalam serum rendah, isohemaglutinin rendah atau bahkan tidak ada, kadar IgE dan IgA normal atau meningkat, kadar IgG normal, jumlah CD8+ rendah (terdapat pada $61 \%$ individu). Limfopenia biasanya muncul pada usia 6 tahun. ${ }^{10}$ Dari data beberapa rumah sakit tempat pasien pernah dirawat didapatkan hemoglobin rendah yang disebabkan oleh perdarahan saluran cerna, dan kadar trombosit yang tidak pernah melebihi 57.000/ul. Kadar IgE dan IgG meningkat serta kadar IgA dan IgM normal. Temuan patologi yang mungkin ditemukan adalah trombosit multipel pada arteriol kecil ginjal, paru, pankreas, hiperplasi limpa, kelenjar getah bening, dan inflamasi pada kulit. ${ }^{10}$ Sayang sekali tidak dapat dilakukan otopsi pada pasien ini dikarenakan pasien meninggal di RS lain.

Diagnosis SWA sangat sulit pada masa bayi karena tidak terdapat kelainan imunologi definitif yang tampak. Gejala dapat berupa respons restricted dari sel limfoid, eksim, bronkhitis, limfoma, dan anemia limfoblastik akut. 
Prosedur diagnosis yang dianjurkan pada pasien tersangka SWA adalah aspirasi sumsum tulang, bukan untuk diagnostik namun dapat membantu untuk menyingkirkan kemungkinan aplasi sumsum tulang atau leukemia. ${ }^{1,10}$ Pada pasien ini telah dilakukan aspirasi sumsum tulang dengan hasil hipoplasia eritropoesis dan trombopoesis. Apakah ini suatu gejala tersendiri atau akibat dari infeksi berat?

Pada pasien ini diagnosis ditegakkan berdasarkan adanya perdarahan, infeksi berulang dan nilai trombosit yang selalu rendah. Perdarahan pada pasien ini bermanifestasi sebagai hematokezia dan purpura, sedangkan pneumonia sebagai akibat infeksi. ${ }^{11-12}$ Pengobatan SWA bersifat simptomatik, yaitu dengan pemberian antibiotik, transfusi darah dan imunoglobulin intravena. ${ }^{10,13}$ Pemberian kortikosteroid atau imunosupresan pada pasien ini oleh karena pada saat itu diduga ITP. Setelah ditegakkan diagnosis SWA maka pemberian kortikosteroid dihentikan karena selain tidak bermanfaat dapat memperberat keadaan imunodefiensi.

Transplantasi sumsum tulang sebaiknya dari saudara kandung yang mempunyai human leukocyte antigen (HLA) yang sesuai, tampaknya dapat memperbaiki semua masalah kecuali trombositopenia. Splenektomi dilakukan apabila ada indikasi khusus seperti trombositopenia dan ukuran trombosit yang kecil, namun perlu diingat bahwa risiko infeksi pasca splenektomi meningkat. Ozsahin dkk. ${ }^{14}$ telah melakukan penelitian retrospektif terhadap 26 kasus SWA yang mendapat transplantasi sumsum tulang dengan hasil yang lebih baik daripada pasien yang mendapat transplantasi sumsum tulang dengan HLA yang secara genetik sama. Transplantasi sumsum tulang dapat memulihkan semua abnormalitas menjadi normal. ${ }^{14}$

Bila telah mencapai masa kanak-kanak maka dapat direncanakan program aktivitas untuk membantu perkembangan motorik secara optimal, misalnya bersepeda (dengan perlengkapan pelindung) atau berenang, hindari kontak dengan infeksi apapun, dan hindari kerumunan orang. Walaupun tidak terdapat diet khusus untuk pasien SWA, ${ }^{1,2}$ namun pada pasien ini diberikan susu formula dengan asam lemak tidak jenuh untuk diare kronis. Edukasi terhadap orang tua, anggota keluarga dan pasien sangat diperlukan terutama dalam upaya pencegahan terhadap infeksi dan keadaan yang akan terjadi. Pemantauan terhadap pasien terutama ditujukan pada, pengobatan infeksi, perkembangan penyakit dan komplikasi. Pada pasien ini penjelasan secara rinci sudah diberikan kepada orangtua. Orang tua cukup mengerti keadaan dan prognosis anak ini, tetapi orangtua tetap optimis dan tetap ingin berusaha memberi pengobatan yang terbaik. Orang tua cukup kooperatif meskipun sudah mengetahui prognosis anaknya kurang baik.

Pencegahan terpenting adalah konseling genetik. Pada karier mungkin didapatkan trombositopenia, tapi biasanya normal atau kadang-kadang bisa diidentifikasi (alel G6PD/petanda kromosom X lainnya). Diagnosis pranatal kadang bisa dilakukan dengan pemeriksaan cairan amnion. ${ }^{2}$

Komplikasi yang mungkin terjadi adalah infeksi berat terutama setelah splenektomi, perdarahan hebat, perhatian khusus pada perdarahan serebral, keganasan (tumor limforetikular, leukemia, sarkoma kaposi), nefropati pada penyakit autoimun termasuk trombositopenia autoimun dan anemia hemolitik, glomerulopati, leukositoblastik atau vaskulitis pembuluh besar, sindrom mirip reumatoid artritis juvenil, kadangkadang penyakit autoimun agresif, atau sindrom malabsorbsi. ${ }^{2}$

Perjalanan penyakit SWA biasanya kronis namun dapat pula mengalami eksaserbasi akut, biasanya fatal sebelum usia 10 tahun; meskipun pernah dilaporkan beberapa pasien tetap hidup hingga usia 20 dan 30an. ${ }^{1,2}$ Penyebab kematian tersering adalah infeksi $(50 \%)$, perdarahan $(27 \%)$, keganasan $(12 \%)$. Pasien ini akhirnya meninggal karena penyakit infeksi paru kanan pada usia 5 bulan. Tatalaksana untuk pasien ini telah diusahakan seoptimal mungkin dengan antibiotik yang sesuai dan transfusi darah merah serta suspensi trombosit; namun menurut kepustakaan tatalaksana pilihan adalah transplantasi sumsum tulang.

\section{Kesimpulan}

Seorang bayi laki-laki usia 3 bulan, semula didiagnosis sebagai ITP sejak lahir yang telah mendapat kortikosteroid, ternyata menderita sindrom Wiskott Aldrich. Diagnosis SWA ditegakkan berdasarkan adanya perdarahan saluran cerna (hematokezia) dan purpura sebagai akibat trombositopenia, eksim pada telinga kanan dan infeksi berulang serta kadar IgE yang sangat tinggi.

Pada SWA yang juga menderita imunodefisiensi, pemberian kortikosteroid akan menyebabkan gejala 
imunodefisiensi makin nyata. Oleh sebab itu bila kita menemukan gejala ITP sejak lahir apalagi dengan infeksi berulang, perlu dipikirkan terlebih dahulu SWA sebelum pemberian kortikosteroid.

\section{Daftar Pustaka}

1. Dambro MR. Wiscott Aldrich syndrome. Dalam: Dambro penyunting. Griffith's 5-minute clinical consult. Lippincott Williams \& Wilkins; 1999. h. 117683.

2. Sullivan KE. Recent advances in our understanding of Wiskott Aldrich syndrome. Curr Opin Hematol. 1999; 6L:8-14.

3. Buckley RH. Primary immunodeficiency diseases. Dalam: Goldman penyunting. Cecil textbook of medicine. Edisi ke-21. Philadelphia: WB saunders company, 2000. h. 1433-52.

4. O’Sullivan E, Kinnon C, Brickell P. Wiskott Aldrich syndrome protein, WASP. Int. J Biochem Cell Biol, 1999; 331:383-7. [serial on line (cided2001 Mar 26); I(I) 2 screen]. Diperoleh dari: URLhttp//www.home.mdconsult.com/das/citation/body/jorg=journalesource $=$ MI\&s $p=10755847 \ldots /$ l.htm.

5. Nonoyama S, Ochs HD. Characterization of the Wiskott Aldrich syndrome protein and its role in the disease. Curr Opin Immunol 1998; 10:407-12. [serial on line (cided2001 Mar 26); I(2)5 screen]. Diperoleh dari: URLhttp://www. home.mdconsult.com/das/citation/body/ jorg $=$ journal\& source $=$ MIEs $p=10503109 . . / \mathrm{l}$.htm .

6. Parolini O, Ressmann G, Haas OA dkk,. X-linked
Wiskott Alddrich syndrome in a girl. N Engl J Med. 1998; 338:291-4.

7. Amman AJ. Combined antibody (B cell) and cellular (T cell) immunodeficiency disorders. Dalam: Stites DP, Terr AI penyunting. Basic and clinical immunology. Edisi ke7. London: Appleton \& Lange; 341-8.

8. Elder ME. Primary immune deficiencies: presentation, diagnosis and management. T-cell immunodeficiencies. Pediatr Clin North Am. 2000; 47(6) [serial on line(cided 2001 Mar 26); I(I)3 screen]. Diperoleh dari: URL http/ lwww. home.mdconsult.com/das/yearbook/body/jorg= journal \&source $=M I$ \& sp $=11122518 \ldots / \mathrm{l}$.htm .

9. Amman AJ, Hong R. Disorders of the T cell system. Dalam: Immunologic disorders in infants and children. Philadelphia: WB Saunders Company, 1989. h. 276-280.

10. Wooniecka M, Ballow M. Primary immune deficiencies: presentation diagnosis and management. Office evaluation of children with recurrent infection. Pediatr Clin North Am. 2000. h. 47 [serial on line(cided 2001 Mar 20); I(5)14 screen). Diperoleh dari: URL http:// www.home.mdconsult.com/das/

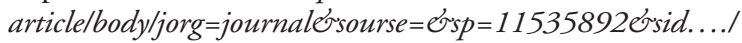
i.htm.

11. Homans A. Trhombocytopenia in the neonate. Pediatr Clin North Am 1996; 43(3):737-56.

12. Lawson SE, Thompson L, Williams MD. Wiskott Aldrich syndrome presenting as congenital thrombocytopenia. Clin Lab Haematol. 1999; 21(6):397-9.

13. Sigal LH, Ron Y. Immunology and inflammation basic and clinical consequences. New York: McGraw-Hill, 1994. h. 314,435-6.

14. Ozsahin H, Deist FL, Benkerrou et al. Bone marrow transplantation in 26 partient with Wiskott Aldrich sindrom from a single center. J Pediatr 1996; 129:238244. 